ks. Wiesław Przyczyna (oprac.)

\title{
Werbalne i niewerbalne środki wyrazu w homiliach do dzieci
}

Tekst jest zapisem dwóch debat (Krzeszowice 2008, Kraków 2009), w czasie których zastanawiano się nad możliwością wykorzystania nowych technologii i różnego rodzaju rekwizytów w przepowiadaniu homilijnym. Najciekawsze fragmenty tych debat zostały zamieszczone w niniejszym podsumowaniu.

\section{Obraz elektroniczny w homilii?}

Ks. Wiesław Przyczyna': W kościołach coraz częściej pojawiają się rzutniki multimedialne. Zazwyczaj służą one do wyświetlania tekstów pieśni. Od pewnego czasu można je także zobaczyć na ambonie. Niekiedy pomagają homiliście, ilustrując jakieś historie. Czasem - w ekstremalnych sytuacjach - zastępują go, gdy homilia jest wyświetlana na ekranie w programie

1 Wiesław Przyczyna - ksiądz profesor doktor habilitowany, homileta, teolingwista, Katedra Komunikacji Religijnej Uniwersytetu Papieskiego Jana Pawła II w Krakowie. 
PowerPoint, a on słucha jej razem z pozostałymi uczestnikami liturgii. Co o tym wszystkim sądzić?

Ks. Andrzej Draguła ${ }^{2}$ : Spór o rolę obrazu trwa od starożytności chrześcijańskiej. Papież Grzegorz Wielki napisał do biskupa Marsylii Serenusa: „To, że zakazałeś czcić obrazy - to bardzo dobrze, ale to, żeś je wyrzucił - to bardzo źle". Grzegorz Wielki zauważył, że obrazy przypominają o rzeczach minionych tym, którzy nie potrafią czytać. Ta kategoria nieczytających będzie nieustannie obecna wśród adresatów nauczania Kościoła. Pewna dwoistość w metodzie ewangelizacji istnieje do dzisiaj: z jednej strony słowo dla intelektualistów, a z drugiej strony - obraz dla tych, którzy nie będą zdolni do odbioru przekazu słownego. Obraz musi być jednak dopełniony przez słowo, które jest właściwym nośnikiem Objawienia. Cały problem ikonoklazmu w Kościele był zmaganiem się o to, aby w przekazie Ewangelii nie doszło do zdominowania słowa przez obraz, który z natury swojej jest łatwiejszy w odbiorze. Tymczasem dzisiaj w duszpasterstwie, niestety, obraz zaczyna dominować. Kościół powinien sprzeciwić się tej tendencji.

Ks. Przemysław Nowakowski: Do czego może doprowadzić nadużywanie obrazu w liturgii, możemy dostrzec w średniowieczu. Istniało wtedy coś takiego, co nazywano pragnieniem „widzenia Hostii”. Ludzie zbliżali się do ołtarza, żeby zobaczyć Hostię. Niektórzy rozumieli to jako tzw. spożywanie przez

\footnotetext{
2 Andrzej Draguła - ksiądz doktor habilitowany, profesor US, homileta, pastoralista (specjalność: komunikacja religijna), Katedra Teologii Pastoralnej, Liturgiki i Homiletyki Uniwersytetu Szczecińskiego.

3 Przemysław Nowakowski CM - ksiądz doktor habilitowany, profesor UPJPII, liturgista, kierownik Katedry Historii Liturgii Uniwersytetu Papieskiego Jana Pawła II w Krakowie.
} 
spojrzenie. Jaki był tego skutek? Wystarczyło zobaczyć Hostię, a wtedy nie trzeba było jej przyjmować. Do „widzenia Hostii” przywiązywano tak duże znaczenie, że ludziom w stanie grzechu ciężkiego nie wolno było na nią patrzeć. Ta „pobożność wizualna" nie prowadziła jednak do przeżywania Eucharystii jako pamiątki śmierci i zmartwychwstania Pana, gdyż wzrok zatrzymywał się na materialnej stronie Hostii unoszonej w czasie podniesienia. Dlatego Sobór Laterański IV musiał nakazać przyjmowanie Komunii Świętej przynajmniej raz w roku. „Pobożność wizualna” jest dużym zagrożeniem, bo spłyca chrześcijaństwo, a praktyki, o których tu mówimy, ku płyciźnie prowadza.

Ks. Andrzej Draguła: Walter Ong zwraca uwagę na różnicę pomiędzy percepcją słuchową i wzrokową. Widzenie jest czynnością podejmowaną z dystansu - trzeba stanąć w pewnej odległości, żeby coś zobaczyć. Natomiast słyszenie jest czynnością, która zanurza nas w dźwięk, bo dźwięk dociera do nas z każdej strony. O ile widzenie jest czynnością indywidualną (obraz skupia na relacji pomiędzy oczami a obrazkiem), to słyszenie tworzy grupę. A więc jeżeli obraz będzie rozdzielał, to dźwięk będzie jednoczył. Obraz jest zawsze powierzchowny, zaś słowo o wiele bardziej objawia tego, który mówi.

Ks. Wiesław Przyczyna: Czy w związku z tym w homilii nie ma miejsca dla obrazu elektronicznego?

Ks. Andrzej Draguła: Niekoniecznie. Człowiek ma ciało i domaga się tego, co fizyczne. W relacjach międzyludzkich wprowadzamy przecież jakieś ikonizacje. Obrączka jest ikonizacją miłości. Ludzie, dając sobie prezent albo podając komuś rękę, materialnie, fizycznie wyrażają wzajemną relację, czyli ją ikonizują. Przecież chrztu nie przyjmuje się przez wzbudzenie 
intencji, ale przez polanie głowy wodą. Jeżeli jakiś obraz będzie coś w homilii ikonizował, to być może można go zastosować. Ważne, żeby taką funkcję spełniał.

Ks. Krzysztof Marcyński؛ Ale tą ikonizacją w relacjach międzyludzkich jest nie coś, lecz ludzkie ciało - gest i głos. Podobnie dzieje się w homilii. Na potwierdzenie tego chciałbym przytoczyć zdanie kard. Józefa Ratzingera: „Im więcej aparatów konstruujemy, choćby były one najnowocześniejsze, tym mniej miejsca pozostaje Panu Bogu, Duchowi Świętemu". I jeszcze wypowiedź Pawła VI w encyklice Ecclesiam suam z 1964 r.: "Nie można go [tj. słowa] zastąpić żadnym innym sposobem przekazywania myśli, chociażby odznaczał się on wyjątkową siłą oddziaływania i skutecznością dzięki zastosowaniu zdobyczy techniki - publikacji, radia czy telewizji”. To homilista, ze swoim ciałem i duszą, jest miejscem przemawiania Boga w czasie liturgii i całym sobą ma umożliwić przemówienie przez siebie Bogu, bez wprowadzania w tę rzeczywistość jakichkolwiek narzędzi. Homilista sam staje się swoistym narzędziem (rekwizytem), którym posługuje się Bóg, zachowując całą specyfikę jego osobowości.

Jolanta Antas ${ }^{5}$ : Zgadzam się z moim przedmówcą. Osoba głosząca homilię wyraża siebie. A wyraża siebie przede wszystkim w słowie mówionym i w gestykulacji. I nie potrzebuje do tego żadnych innych dodatkowych środków. Natomiast ze względu na odbiorcę inne środki, w tym obraz elektroniczny, mogą być

\footnotetext{
4 Krzysztof Marcyński SAC - ksiądz doktor, homileta, adiunkt w Instytucie Edukacji Medialnej i Dziennikarstwa Uniwersytetu Kardynała Stefana Wyszyńskiego w Warszawie.

5 Jolanta Antas - profesor doktor habilitowany, językoznawca, Katedra Teorii Komunikacji Wydziału Polonistyki Uniwersytetu Jagiellońskiego w Krakowie.
} 
pożyteczne, żeby uruchomić jego wyobraźnię. Jednak liczba tych środków nie powinna być duża. Widzieliśmy prezentację księdza Pawła, w której obraz w programie PowerPoint zdominował cały przekaz: było $\mathrm{w}$ nim wiele informacji, ale mało księdza Pawła ${ }^{6}$. Środki są potrzebne, ale ich przerost będzie zabójczy dla komunikacji.

Ks. Krzysztof Marcyński: Moim zdaniem jednak obraz elektroniczny nie uruchamia wyobraźni. Zwróćmy uwagę na to, w jaki sposób niektórzy ludzie reagują po obejrzeniu misteriów pasyjnych, które od czasów średniowiecza do dzisiaj są przygotowywane w niektórych parafiach: „zupełnie inaczej wyobrażałem sobie Chrystusa". Spójrzmy na filmowe adaptacje powieści. Okazuje się, że olbrzymia większość tych adaptacji jest zubożeniem samej powieści. Tak działa obraz. To pokazuje, że obraz każe mi przyjmować rzeczywistość taką, jaka została pokazana. Natomiast jeśli słyszę słowo, to ono działa we mnie jak bomba kasetonowa - pobudza moją wyobraźnię i porusza moje wewnętrzne doświadczenie Jezusa, uruchamiając moje o Nim wyobrażenie. Dopiero wtedy dochodzi do komunikacji z Bogiem.

Ks. Andrzej Draguła: Myślę, że są sytuacje, kiedy obraz elektroniczny może być wykorzystany w celach ilustracyjnych. Po co mam opisywać scenę powołania Mateusza, kiedy mogę ją pokazać? Jednak jeśli obok siebie postawimy słowo i obraz, to nie ulega wątpliwości, że obraz zawsze będzie nas bardziej pociągał. Jeśli obraz przestanie spełniać funkcję ilustracyjną,

\footnotetext{
6 Chodzi tu o wystąpienie ks. Pawła Rozpiątkowskiego, który podczas debaty w Krakowie zaprezentował sposoby wykorzystania rzutnika multimedialnego w głoszeniu homilii.
} 
a zdominuje cały przekaz, to znaczy, że granica jego wykorzystania w homilii została przekroczona. Ale możliwość przekroczenia owej granicy chyba nie przekreśla od razu samej możliwości posługiwania się nim w homilii.

Jan F. Jacko7: Elektroniczny obraz to swoisty znak. Jest to znak wirtualny, który może się kojarzyć z elektronicznymi środkami przekazu, zwłaszcza z telewizją lub kinem. Przez to skojarzenie znak ten wprowadza swoisty dla siebie klimat. Nośnikiem sensu w tym znaku są promienie z projektora odbite od ekranu. Dotychczas znaki należące do liturgii nie miały tego nośnika (jeśli nie liczyć tekstów pieśni wyświetlanych z rzutnika). Wskazane tu skojarzenie i nietypowość mogą być i często są odbierane jako niepasujące do liturgii. To, co nazywam tu klimatem, nie jest tylko sprawą gustów. Klimat powstaje m.in. przez dobór i sposób używania znaków, co można nazwać też stylem, językiem, semantyką. Zmiana klimatu homilii jest możliwa i możliwe jest, że kiedyś elektroniczne obrazy zaczną do niego należeć. Na razie tak nie jest. Decyzja o zmianie stylu wymaga uzasadnienia przez odpowiedź na pytanie: Czemu ma służyć i jakie sa pastoralne "koszty” tej zmiany? Wprowadzanie elektronicznego obrazu jest uzasadnione, jeśli spełnia on rolę istotną dla homilii, której nie są w stanie spełnić słowa i gesty, a zarazem taką, która nie zakłóci funkcjonowania innych znaków należących do liturgii. W innym razie zmiana jest niepotrzebna, a nawet może okazać się szkodliwa. To, co tu powiedziałem, nie jest odpowiedzią na pytanie, to jest inne jego sformułowanie. Odpowiedź na nie wymagałaby skrupulatnej analizy przy-

\footnotetext{
7 Jan Franciszek Jacko - doktor habilitowany, filozof, aktor, trener komunikacji, Wydział Zarządzania i Komunikacji Społecznej Uniwersytetu Jagiellońskiego w Krakowie.
} 
kładów pod względem funkcji obrazu elektronicznego i celów homilii. Prawdopodobnie w większości przypadków, wprowadzając elektroniczny obraz do liturgii, traci się więcej, niż się zyskuje pod względem pastoralnym, ale nie wykluczam wyjątków od tej reguły. Ten rachunek zysków i strat wypadnie inaczej w liturgii, a inaczej poza liturgią; inaczej, gdy głosiciel umie ciekawie mówić i trafnie gestykulować, a inaczej, gdy nie radzi sobie z tymi środkami ekspresji; inaczej, gdy słuchacz jest osobą dorosłą, a inaczej, gdy słuchaczem jest dziecko lub ktoś niedojrzały, itd. Funkcje znaków można do pewnego stopnia badać metodami empirycznymi. Z pewnością ciekawą rzeczą byłoby przebadanie tego, jak się zmienia percepcja homilii przez wprowadzenie wirtualnego obrazu.

Elżbieta Dryll: Wydaje mi się, że najbardziej groźne byłoby takie użycie obrazu elektronicznego, które głoszącego homilię zwalniałoby z autorstwa przekazu. Jeżeli natomiast obraz nie zastępuje głoszącego, tylko wzmacnia jego przekaz, to trzeba go poprzeć.

Ks. Henryk Sławiński: Tutaj dotykamy istotnego aspektu przepowiadania, jakim jest świadectwo homilisty. Według badań przeprowadzonych w Stanach Zjednoczonych tym, czego słuchacze oczekują najbardziej, jest świadectwo wiary głosiciela, i to zarówno poza liturgią, jak i podczas liturgii. Prezentacja komputerowa utrudnia świadczenie, bo staje się w dużym stopniu niezależna od autora. Słowo natomiast ujawnia osobowość

\footnotetext{
8 Elżbieta Dryll - profesor doktor habilitowany, psycholog, Zakład Psychologii Wychowania Wydziału Psychologii Uniwersytetu Warszawskiego.

9 Henryk Sławiński - prezbiter diecezji włocławskiej. Profesor doktor habilitowany, homileta i pedagog. Pracuje na Wydziale Teologicznym Uniwersytetu Papieskiego Jana Pawła II w Krakowie.
} 
homilisty oraz jakość jego przygotowania i zaangażowania w wydarzenia, jakim jest celebracja liturgiczna.

Eugeniusz Wilk ${ }^{10}$ : Wydaje mi się, że w naszej dyskusji zaczynamy stąpać po kruchym lodzie i nie zawsze dostrzegamy, że wkraczamy na obszar fundamentalnych sporów na temat współczesnej kultury. Dotykamy kwestii związanych z tzw. zwrotem obrazowym. To kolejny, po „zwrocie językowym”, przełom, który - jak pamiętamy - głęboko przeorał współczesną myśl filozoficzną i kulturoznawczą. Niektórzy komentatorzy mówią, że na naszych oczach powstaje nowy paradygmat kulturowy i zarazem teoriopoznawczy, w znaczeniu, które zaproponował Thomas S. Kuhn. W naszej dyskusji nie możemy tracić z pola widzenia tego kontekstu. Gdy przyglądamy się tym kwestiom, to dostrzegamy, że twierdzenia Gombricha o tym, że nasz wiek jest epoką obrazu, epoką, w której „obraz zwycięży słowo pisane", jest już niewystarczające, gdyż nie oddaje złożoności tej problematyki. Postaram się w możliwie największym skrócie wskazać na konsekwencje tego zwrotu. W. J. T. Mitchell pisze, że w przypadku zwrotu obrazowego mamy do czynienia „ze złożoną grą między wizualnością, zmysłami, instytucjami, dyskursem, ciałem i figuratywnością". Zwróćmy uwagę na to, że „instytucje” zanurzają nas w przestrzeń uwarunkowań technologicznych i społecznych. Już Walter Benjamin pisał, że obraz reprodukowany technologicznie traci bezpowrotnie swą aurę, czyli m.in. "naturalny” niekiedy związek ze sferą sacrum. Zauważmy, że spostrzeżenie to dotyczy również przestrzeni telepiśmienności (cyberdyskursywności) nowych

\footnotetext{
1o Eugeniusz Wilk - profesor doktor habilitowany, kierownik Katedry Mediów Audiowizualnych Instytutu Sztuk Audiowizualnych Uniwersytetu Jagiellońskiego w Krakowie.
} 
mediów. Słowo zapośredniczone medialnie zyskuje bowiem w coraz większym stopniu status obrazowy - jest obrazem stricte technologicznym. To ma swoje dalsze, głębsze konsekwencje, jeśli uświadomimy sobie, że w gruncie rzeczy posługujemy się mediami cyfrowymi, które z natury redefiniują w dużej mierze nasze relacje ze światem. Proste i klarowne zasady reprezentacji semantycznej ulegają erozji i fundamentalna zasada mimesis zostaje podana w wątpliwość. Chcę być dobrze zrozumiany. Nie trzymam się kurczowo tez Baudrillarda. Chodzi mi raczej o rodzaj aktualnej kompetencji, szczególnie młodych ludzi, jakże dobrze obeznanych z multimediami, którzy te swoje doświadczenia odbiorcze w sposób nieuchronny przenoszą na przekaz medialny, który ewentualnie mógłby być częścią homilii. Trzeba wyraźnie powiedzieć: to jest inny porządek aksjologiczny. Dzieje się tak m.in. dlatego, że media cyfrowe mające potencjał generowania obrazów, tzn. tworzenia ich bez konieczności odnoszenia do świata, równocześnie w swoisty sposób „dyscyplinują” (by użyć określenia Foucaulta) swoich użytkowników. Hans Belting, powołując się na McLuhana, formułował tę myśl jeszcze wyraźniej, twierdząc, że „kompetencja nowych mediów przewyższa kompetencję naszych organów cielesnych". Ten lód jest, jak widzimy, nadzwyczaj kruchy, a w dodatku wcale nie mamy pewności, gdzie są jego granice.

Rekwizyty w homilii?

Ks. Wiesław Przyczyna: Na ambonie, obok rzutnika multimedialnego, coraz częściej można zobaczyć różnego rodzaju rekwizyty, np. namalowane na kartonie drzwi, budzik, buty, puszki z piwem, łuki i strzały. Niekiedy rekwizytem staje się druga osoba, np. dziewczyna wcielająca się w rolę owieczki, 
którą homilista niesie na plecach w Niedzielę Dobrego Pasterza. Zdarza się też i tak, że rekwizytem jest sam homilista, który przebiera się za smoka wawelskiego. Czy rzeczywiście homilia potrzebuje tego rodzaju znaków?

Ks. Przemysław Nowakowski: Myślę, że istnieje tu pewien problem. Otóż homilia jest częścią liturgii i nie może być rozważana jako byt istniejący samoistnie. Jeżeli homilista w liturgiczną przestrzeń słowa wprowadza różne rekwizyty, to zmienia naturę liturgii. Ksiądz, który wykorzystuje w homilii wspomniane wyżej środki, tworzy jakby liturgię paralelną do tej, którą sprawuje Kościół, bo tworzy nowy system znaków i symboli. Czy wolno mu to robić? W czasach przed Soborem Trydenckim kazanie, które nie było uznane za część sprawowanej liturgii, głoszono albo wcześniej, albo później, a wtedy wykorzystywano różne środki, jak na przykład: trupie czaszki, obrazy, dramaty liturgiczne, jasełka, teatry itd. One były jednak poza liturgią...

Jan F. Jacko: Zastanawiam się, czy Jezus, mówiąc przypowieść o ziarnie lub o zagubionej owcy, posługiwał się rekwizytami w postaci trzymanych w dłoni ziaren lub wskazywał pasąca się w pobliżu owcę. Te rekwizyty chyba nie były ważne, skoro ewangeliści o nich nie wspominają. W tych przypowieściach słowo wystarcza do stworzenia potrzebnego obrazu. Rekwizyty pojawiają się dopiero wtedy, gdy są niezbędne. Na przykład zdanie "Oddajcie cesarzowi, co cesarskie, a Bogu, co Boskie”, staje się bardziej zrozumiałe, gdy spojrzymy na monetę i zobaczymy tam podobiznę władcy. Tu moneta jako rekwizyt jest ważnym elementem komunikatu, bo zawiera w sobie przemilczaną przesłankę rozumowania, z którego Jezus wypowiada tylko konkluzję. Dlatego zapewne prosi o monetę i pyta słuchaczy o to, co widzą. Taki jakby-happening budzi doświadczenie, 
które jest potrzebne do przeżycia teologicznej treści o obrazie i podobieństwie do Boga, która była dobrze znana jego rozmówcom z biblijnego opisu stworzenia i być może dlatego właśnie jest przemilczana w tej sytuacji, bo o jej przeżycie tu chodzi, a nie o wyrecytowanie znanego fragmentu księgi. Jezus wykorzystuje rekwizyt, by sprowokować słuchaczy do samodzielnego odkrywania analogii, bo samodzielnie dokonane odkrycia zobowiązują bardziej niż czyjeś słowa. Ubogie, ale trafnie dobrane środki wyrazu, mogą skuteczniej ewokować doświadczenie niż ich źle dobrany nadmiar. Rekwizyty nie są potrzebne, gdy wystarcza słowo i gest, ale mogą się pojawić, gdy wnoszą coś ważnego do homilii, o ile oczywiście nie zakłócają klimatu liturgii.

Ks. Bogusław Migut ${ }^{11}$ : W Księdze Wyjścia mamy wyraźny zakaz używania obrazów. Kiedy jednak Bóg każe Izraelitom wspominać wydarzenie ich paschy, to każe im używać pewnych znanych w tradycji symboli: chleba i wina. One mają dla nich głębokie znaczenie. Jeżeli Jezus w czasie Ostatniej Wieczerzy używa jakichś przedmiotów, to są nimi chleb i wino. To nie są jakieś wymyślone na potrzebę chwili rekwizyty. To są symbole, które mają za sobą ogromną tradycję. On dlatego je bierze, bo one jako symbole, mają swoją wartość i znaczenie.

Słowo i gest w homilii?

Ks. Wiesław Przyczyna: Z naszej dyskusji wynika, że podstawowym środkiem przekazu orędzia zbawczego w homilii jest słowo. Powstaje pytanie: Jakie to powinno być słowo? Czym się

\footnotetext{
11 Bogusław Migut - ksiądz doktor habilitowany, profesor KUL, liturgista, Katedra Duchowości Liturgicznej Katolickiego Uniwersytetu Lubelskiego.
} 
ono ma charakteryzować, by mogło trafić do współczesnego człowieka?

Jolanta Antas: Od czasów starożytnych toczy się spór o kształt słowa. Stronami sporu - z jednej strony - są zwolennicy tezy, że słowo niesie w sobie istotę rzeczy, z drugiej zaś ci, którzy twierdzą, że słowo jest wyłącznie sprawą umowną. W XX w. przeważył pogląd, że język jest konwencjonalny, czyli jest umownym środkiem przekazywania myśli, a w konsekwencji jego obrazowość (ikoniczność) ma znikome znaczenie. Dopiero językoznawstwo kognitywne odkryło, że myślenie ikoniczne, nie zaś arbitralne, jest dla języka pierwotne.

Ks. Wiesław Przyczyna: Zanim przejdziemy do tematu języka ikonicznego, porozmawiajmy chwilę o samej ikoniczności, czym ona jest, na czym polega, jakie są jej typy.

Jolanta Antas: Pojęcie „ikoniczność” implikuje, że istnieje pewne podobieństwo albo analogia między formą danego znaku a jego obiektem, między słowem i jego realnym przedmiotem. Najłatwiej można to zrozumieć na przykładzie wyrazów dźwiękonaśladowczych (onomatopei): „syczeć”, „drapać”, „krakać”, „wiać”, „na czczo”, „cicho”, „szumieć”, „dudnić” itd.

Ks. Wiesław Przyczyna: I to w językoznawstwie kognitywnym nazywa się ikonicznością obrazową. Czy znane są jeszcze inne typy ikoniczności?

Jolanta Antas: W lingwistyce kognitywnej mówi się o dwu następnych typach ikoniczności: diagramatycznej i semantycznej (metaforze i metonimi). W przypadku ikoniczności obrazowej istnieje audytywne bądź kinetyczne połączenie między 
znakiem a desygnatem. W przypadku ikoniczności diagramatycznej nie ma bezpośredniego połączenia między znakiem i jego desygnatem; to raczej struktura znaku lub zestawienie znaków na poziomie językowym przypominają sposób, w jaki owe desygnaty są uporządkowane $\mathrm{w}$ świecie rzeczywistym, czyli w zgodzie z naszą percepcją świata. Innymi słowy, ikoniczność diagramatyczna dotyczy zasad budowania struktury wypowiedzeniowej (składni, gramatyki), tak że odzwierciedla ona naturalny porządek poznawczy i percepcyjny człowieka. Ten typ ikoniczności opiera się na trzech zasadach: 1. na zasadzie sekwencyjnej (składnia odbija naturalny przebieg zdarzeń, np. veni, vidi, vici); 2. na zasadzie ilościowej (formy mnogie są zazwyczaj dłuższe od liczby pojedynczej; reduplikacja wyrazów jest częstym chwytem językowym na tworzenie liczby mnogiej, np. język zulu: cow-cow - krowy; działa tu też zasada: więcej formy - więcej treści, np. „on biegnie i biegnie”); 3. na zasadzie dystansu (elementy znajdujące się blisko siebie w sensie pojęciowym są także sobie bliższe na poziomie językowym, np. "Kupiłem tę książkę dla Jana” i „Kupiłem tę książkę Janowi” dativus bardziej gwarantuje, że Jan będzie tę książkę miał).

\section{Ks. Wiesław Przyczyna: I trzeci typ ikoniczności?}

Jolanta Antas: Trzeci typ ikoniczności, zwany ikonicznością semantyczną, dotyczy sposobu obrazowania myśli. W zasadzie każde połączenie wyrazowe, które wywołuje obraz lub doznania kinetyczne, ma charakter ikoniczności semantycznej, np. słyszymy: „świeże wiadomości”, „lek kie oprocentowanie”, "pły tkie słowa”, „głębo kie myśli" itp. Wiele metaforycznych i metonimicznych językowych rozszerzeń wynika z fizycznych i zmysłowych doświadczeń człowieka. Mówimy na przykład: "prowizja banku zjadła twoje zyski”, „te pojęcia się ze sobą 
z a z ę bi a ją”, „sło d ka zemsta” itp. Także zbitki słowotwórcze mogą mieć charakter metaforyczny, np. ,jesteś g o ło sło w n y" (gołe słowo, nieubrane). Mówimy też, gdy chcemy, by coś miało sens: „niechby ten pomysł, projekt miał ręc e i nogi”. Generalnie na podstawie doświadczenia takich właściwości fizycznych jak: jasny/ciemy, zimny/ciepły, wielki/mały, silny/słaby itp. możemy w nieskończoność produkować metafory typu: „jas ny, klarowny wywód”, „mroczne myśli”, „gorąca debata". Szczególnie metaforyczny charakter mają wszystkie pojęcia abstrakcyjne. Za pomocą metafor bowiem wyraża się to, co w języku nie ma jeszcze gotowych formuł, dlatego tak często posługują się nimi naukowcy, filozofowie, poeci, mistycy.

Ks. Wiesław Przyczyna: Nie tylko oni, ale także głosiciele słowa Bożego.

Jolanta Antas: Oczywiście, sadzę, że ikoniczność językowa, żywa i świeża metafora musi (a nie tylko może) być nieodzownym narzędziem każdego religijnego przekazu.

Ks. Wiesław Przyczyna: Czy każda metafora? A co z metaforami, które utraciły swoją metaforyczność?

Jolanta Antas: Użycia niedosłowne wielokrotnie powtarzane zyskują z czasem samodzielne znaczenie i ich metaforyczność się zaciera. O takich zwrotach metaforycznych, których niedosłowność się zatarła, mówimy, że są wytarte, martwe. Martwą metaforą są na przykład sformułowania: „czas ucieka”, „podupadać na duchu”. W języku religii do takich martwych metafor należą: „Pan Bóg”, „królestwo niebieskie”, „dom naszego Ojca w niebie”, „zło bardzo lubi odziewać się w szaty dobra" itp. 
Ich opozycją są metafory żywe, niekonieczne mające poetycki charakter, lecz kreatywne, zmuszające do zmian w rozumieniu świata. Dziś już nie „odziewamy się w szaty”, ale możemy „się stroić". Nowy świat myśli wymaga nowego ich wyobrażenia i nowej ożywionej metaforyki, ale nie takiej, jak te próby: „Boże Narodzenie to inwazja na siły ciemności”, „Bóg jest magazynem łaski" itp.

Ks. Wiesław Przyczyna: To w takim razie jak budować metafory żywe?

Jan F. Jacko: Jedną z funkcji obrazów budowanych słowem jest wiązanie przekazywanej treści z doświadczeniem życiowym słuchacza. Gdy na przykład mowa o zagadnieniach teologicznych lub moralnych, to warto nawiązać do tego, co dobrze znane i zrozumiałe, a następnie pokazać analogię do tego, o czym mowa (a nie odwrotnie, jak się to czasem zdarza). Przypowieści w Nowym Testamencie pokazują metodę budowania obrazu: Trzeba wyjść od doświadczenia słuchacza, spojrzeć na jego świat jego oczami, odnaleźć w nim swoiste dla jego świata symbole i tymi symbolami mówić do niego. Do pasterzy - o zagubionej owcy, do rolników - o ziarnie, do celników o talentach itp.

Ks. Wiesław Przyczyna: Innym sposobem obrazowania jest gestykulacja. Jaka jest jej rola w międzyludzkiej komunikacji?

Aneta Załazińska ${ }^{12}$ : Gesty towarzyszące słowom są z nimi ściśle związane. Liczne badania i eksperymenty (nie tylko psy-

\footnotetext{
12 Aneta Załazińska - doktor habilitowany, językoznawca, Katedra Teorii Komunikacji Wydziału Polonistyki Uniwersytetu Jagiellońskiego w Krakowie.
} 
chologiczne czy językoznawcze, ale także z zakresu neurobiologii) pokazują, że gesty i słowa współtworzą wypowiedź i w zadziwiający sposób, dopełniając się nawzajem, wyrażają idee i intencje mówiącego.

Wśród licznych kategorii gestów możemy wyróżnić gesty narracyjne i gesty afektów, które wyrażają emocje. I tak na przykład, mówiąc, że jakieś pojęcia łączą się ze sobą, często pokazujemy jednocześnie gest splecionych dłoni. I to jest gest narracyjny, ilustrujący. Jeśli zaś zaczęlibyśmy stukać palcami w stół, to byłoby to zachowanie afektywne - ten gest wyrażałby emocje. Nie ilustruje on wypowiadanej myśli, ale pokazuje stan psychiczny, emocje, komfort lub dyskomfort konwersacyjny.

Z punktu widzenia retoryki, perswazyjności przekazu roli gestów narracyjnych nie sposób przecenić. Gesty te nie są prostymi ilustracjami wypowiadanych myśli, ponieważ odnoszą się do samego zamysłu, samej idei, którą mówiący rzeczywiście chce przekazać. Myśl jest więc wyrażana na dwa sposoby: przez słowo i przez gest. Język jednak jest linearny, rozczłonkowany, analityczny; pozwala ująć myśl w zorganizowane składniowo, ale pojedyncze słowa. Tymczasem gest ma charakter syntetyczny, globalny - pozwala ująć ideę całościowo. Co jednak ważne, te dwa sposoby wyrażania nie konkurują ze sobą, ale dopełniają się nawzajem. Gestykulujemy, bo odruchowo wykorzystujemy komunikacyjny potencjał naszego ciała dla zobrazowania własnych myśli, które chcemy przekazać odbiorcom.

Jolanta Antas: Co więcej, kiedy człowiek jest głęboko przekonany do wypowiadanych przez siebie idei i mocno w nie wierzy, kiedy sam jest bogaty duchowo i intelektualnie, wówczas będzie potrafił zobrazować swoje myśli i w naturalny sposób będzie posługiwał się gestykulacją, by wypowiedzieć siebie 
całym swoim ciałem. Natomiast powstrzyma się od gestykulowania, kiedy nie wierzy w głoszone idee albo kiedy kłamie.

Aneta Załazińska: Dlatego nie należy blokować naturalnego odruchu gestykulowania, choć u różnych osób potrzeba gestykulowania w różnym stopniu się ujawnia. Różnimy się bowiem stylami ekspresji niewerbalnej. Obecnie wiemy już z całą pewnością, że gestykulacja służy zarówno odbiorcom, jak i samym nadawcom komunikatów. Gestykulacja sprawia, że przekaz staje się żywszy, bardziej plastyczny i daje wrażenie autentyczności. To zalety, które docenią odbiorcy. Gesty wspomagają jednak także samego mówiącego - ich wykonawcę. Badania pokazały, że gdy mówiącemu zabroni się stosowania gestów narracyjnych lub je w sposób sztuczny zablokuje, to jego narracja traci na jakości, staje się niespójna i bardziej chaotyczna.

Docenienie roli gestów w komunikacji nie jest zakwestionowaniem roli słowa. Wręcz przeciwnie, ukazuje jego wyjątkowość i niepowtarzalność jako środka ekspresji. Gest i słowo są bowiem odmiennymi, różnymi sposobami wyrażania znaczeń. Różnice te sprawiają jednak, że słowo i gest w komunikacji współwystępują, nawzajem się dopełniają i nawzajem potrzebuja.

Jan F. Jacko: Ale nawet spontaniczne gesty bywają sztuczne i źle dobrane. Gestykulację, tak jak każdą umiejętność, trzeba rozwijać. W niektórych środowiskach uczenie się mowy ciała bywa kojarzone ze sztuką manipulacji i udawania, ale jest to mylne skojarzenie. Gestem, podobnie jak słowem, można kłamać lub nie. Można się uczyć mowy ciała po to, by być bardziej zrozumiałym dla słuchacza. 


\section{Wnioski pastoralne}

Ks. Wiesław Przyczyna: Co więc leży u podstaw tego, że homiliści tak chętnie sięgają po rzutniki czy też różnego rodzaju rekwizyty? Dlaczego nie wystarczają im słowa i gesty jako podstawowe środki przekazu orędzia zbawczego?

Ks. Henryk Sławiński: To są ważne pytania. Myślę, że można wskazać kilka przyczyn. Po pierwsze w praktyce katechetycznej w wyniku lepszego przygotowania pedagogicznego katechetów obserwujemy rozwój metod aktywizujących, które później zaczynają być stosowane w homilii. Po drugie wskazałbym na popularność kursów ewangelizacyjnych wykorzystujących m.in. różne formy teatralne, które poruszają ich uczestników, rodzą zainteresowanie i popularność tychże kursów. Być może później pojawiają się próby przeniesienia tych doświadczeń do liturgii. Po trzecie dzięki Internetowi mamy łatwy dostęp do opracowanych pomocy homilijnych, wraz z gotowymi prezentacjami multimedialnymi. Łatwy dostęp rodzi pokusę sięgnięcia po nie tym większą, że ich wykorzystanie $\mathrm{w}$ homilii daje poczucie bycia nowoczesnym i atrakcyjnym, a także złudzenie lepszego dostosowania języka przepowiadania do mentalności współczesnego człowieka. Po czwarte niedowartościowanie homilii od strony misterium. Wreszcie po piąte, jak sądzę - najważniejsze, rodząca się w wielu kapłanach subiektywna świadomość małej skuteczności własnego przepowiadania, co mobilizuje ich do poszukiwania nowych form.

Elżbieta Dryll: W dydaktyce konieczność stosowania prezentacji multimedialnych stała się dzisiaj rodzajem niepodważalnej prawdy, więc ulegamy zbiorowej presji wywołanej przekonaniem, że bez multimediów przekaz będzie nie tylko 
mało interesujący, ale również nieskuteczny. Być może takiej presji ulegają również kapłani. Ponadto zastosowanie jakiegoś medium elektronicznego jest łatwiejsze: naciskam „enter” i przekaz się rozpoczyna. Powiem więcej, zastosowanie medium daje poczucie większego bezpieczeństwa, tym bardziej jeśli wykorzystana prezentacja została przygotowana przez kogoś innego (w domyśle: specjalistę). Myślę, że może mieć miejsce postawa, którą nazwałabym „chowaniem się” za rekwizyty lub prezentacje multimedialne.

Jaka jest na to rada? Co mogłoby pomóc księżom (i nie tylko księżom) mówić sobą? Wyobrażam sobie proboszcza, który na co dzień ma bliski kontakt z parafianami: on idzie do nich, oni przychodzą do niego, dzielą się swoimi codziennymi przeżyciami. Nie boi się zaczepić na ulicy pijaka, by zapytać, jak $\mathrm{mu}$ się wiedzie. Kiedy przychodzi do domu z wizytą duszpasterską, to rzeczywiście pragnie się z nimi spotkać, stając w miejscu, w którym żyją. Później, kiedy będzie się zastanawiał nad niedzielną liturgią słowa i tekstem swojej homilii, to w jego myśleniu te codzienne doświadczenia spotkań z parafianami będą obecne, a homilię będzie mógł skierować do konkretnych osób, które będą pod wrażeniem, że jest ona przepowiadana bezpośrednio do nich. Wtedy komunikacja niewerbalna, czyli kontakt wzrokowy, gestykulacja lub ewentualne rekwizyty pojawią się naturalnie.

Aneta Załazińska: Sądzę, że powodem sięgania podczas homilii po różnego rodzaju rekwizyty czy prezentacje multimedialne może być brak sprawności w posługiwaniu się słowem mówionym (a może również brak zaufania co do posiadanych umiejętności posługiwania się nim).

Korzystając z moich doświadczeń nabytych w Podyplomowym Studium Retoryki działającym przy Wydziale Polonistyki 
UJ, gdzie w zajęciach uczestniczą zarówno księża, jak i świeccy, mogę powiedzieć, że problemem wielu ludzi dzisiaj jest brak elementarnych umiejętności retorycznych. Mam na myśli zdolność przełożenia tekstu pisanego (uprzednio przygotowanego) na język mówiony. Myślę, że wynika to między innymi stąd, że w trakcie edukacji szkolnej uczymy się pisać, przedstawiać temat $\mathrm{w}$ formie pisanej, ale nie uczymy się jego prezentowania, czyli nie uczymy się mówienia (wygłaszania czegoś) przed innymi i do innych. Skutkiem tego jest pewien lęk przed wypowiadaniem się. Jest to jeden z powodów, dla których wielu ludzi w swoich wystąpieniach publicznych nie potrafi oderwać wzroku od kartki z przygotowanym tekstem. Podkreślam, nie jest to problem jedynie księży. Brak umiejętności wypowiadania się rodzi lęk przed wystąpieniem publicznym bez kartki, która to daje poczucie bezpieczeństwa oraz pewność, że wypowiedź będzie bardziej klarowna i bardziej elegancka. Język pisany to jednak nie to samo co język mówiony. Tekst odczytany to nie tekst wygłoszony.

Jan F. Jacko: Jeśli homilista ma dobre przygotowanie i talent oratorski, to dodatkowe środki ekspresji będą mu przeszkadzać, gdyż odwracają uwagę słuchaczy od jego słów i gestów. Będzie sięgał po rekwizyt lub obraz multimedialny tylko wtedy, gdy nie jest w stanie bez niego dotrzeć do słuchacza. Taka sytuacja zdarza się rzadko, ale może się zdarzyć, na przykład gdy słuchaczami są dzieci.

Ks. Przemysław Nowakowski: Według mnie jednym z zasadniczych problemów jest kwestia rozumienia i przeżywania liturgii, a zwłaszcza zagubienie jej misterium. A ten problem wynika w dużym stopniu ze słabej formacji liturgicznej i homiletycznej w seminariach duchownych. W wielu przypadkach homilia 
w dalszym ciągu jest traktowana niezależnie od jej liturgicznego kontekstu.

Ks. Jarosław Superson ${ }^{13}$ : Aby przygotować się do tej dyskusji, sięgnąłem po pierwszy podręcznik, jaki miałem pod ręką, a który powinien mieć każdy student liturgiki, czyli po Leksykon liturgii. Szukam w nim terminu "misterium” i... okazuje się, że terminu takiego w nim nie ma. Potem szukam terminu „tajemnica” i... też nie ma. Trudno jest dyskutować nad użyciem PowerPointa w homilii, skoro podczas tego panelu nie zauważyliśmy kluczowego zagadnienia - „misterium Chrystusa, które zawsze jest w nas obecne i działa, zwłaszcza w obrzędach liturgicznych" (KL 35). Jeśli PowerPoint byłby użyty w liturgii, musiałby nie tylko podtrzymywać, ale aktualizować liturgię jako moment zbawczy, jako misterium Chrystusa. Czy jest w stanie to uczynić?

Ks. Wiesław Przyczyna: Czy jedną z przyczyn wprowadzania multimediów do homilii nie jest również to, że zarówno sami głosiciele, jak i ich słuchacze są dziećmi naszej epoki, czyli doświadczają w sobie skutków ich działania? Czy nie warto zatem, licząc się nawet $\mathrm{z}$ tym, że utracimy pewne znaczenia, sięgać po nowe technologie, by odpowiedzieć na oczekiwania naszych słuchaczy, którzy są dziećmi współczesności?

Ks. Andrzej Draguła: Doskonale rozumiem poszukiwania ks. Pawła i innych księży. Mam przecież na swoim sumieniu powstanie tzw. Biblii hip-hopowej, w której opracowaniu uczestniczyłem na pewnym etapie. Mam świadomość,

\footnotetext{
13 Jarosław Superson SAC - ksiądz doktor habilitowany, liturgista, Katedra Teologii Liturgii Uniwersytetu Papieskiego Jana Pawła II w Krakowie.
} 
że żyjemy w świecie wolnego rynku i pokusa potraktowania religii jako jednego z towarów oferowanych w naszym kramie stojącym pośród innych kramów towarzyszy nam nieustannie. To ona sprawia, że czasami próbujemy przebić się z naszą ofertą, poszukując, zgodnie z zasadami marketingu i reklamy, coraz bardziej atrakcyjnego i nowoczesnego sposobu zaprezentowania swojego kramu. To samo próbujemy uczynić z liturgią. Tymczasem liturgia nigdy nie będzie atrakcyjna, gdy chodzi o formę jej sprawowania. Nie da się zmienić formy bez naruszenia jej istotnej treści. Dlatego możemy przebić się nie tyle zewnętrzną atrakcyjnością naszego kramu, nawet nie tym, że nasz kram jest najlepszy, ale tym, że jest on zasadniczo różny od innych kramów i dlatego może wzbudzić zainteresowanie. $\mathrm{Z}$ tego powodu ważna jest troska o to, aby liturgia wraz ze swoją integralną częścią, jaką jest homilia, pozostały sobą.

Ks. Wiesław Przyczyna: Podsumowaniem naszej debaty niech będą słowa Jana Pawła II, który doceniając współczesne środki przekazu, powiedział: „Ale nic nie może zastąpić obecności biskupa, który zasiada na katedrze albo staje na ambonie swojego biskupiego kościoła i osobiście wykłada słowo Boże tym, których wokół siebie zgromadził". 